\title{
СРАВНИТЕЛЬНЫЙ АНАЛИЗ РАЗВИТИЯ ОТЕЧЕСТВЕННОГО И ЗАРУБЕЖНОГО ЗАКОНОДАТЕЛЬСТВА, ПРЕДУСМАТРИВАЮЩЕГО ОТВЕТСТВЕННОСТЬ ЗА ВОВЛЕЧЕНИЕ НЕСОВЕРШЕННОЛЕТНЕГО В СОВЕРШЕНИЕ ПРЕСТУПЛЕНИЯ
}

COMPARATIVE ANALYSIS

OF THE DEVELOPMENT OF DOMESTIC AND FOREIGN LEGISLATION PROVIDING FOR RESPONSIBILITY FOR INVOLVING A MINOR IN THE COMMISSION OF A CRIME

I. Avdeev

Summary. The purpose of this study is to analyze the development of domestic and foreign legislation providing for responsibility for involving a minor in the commission of a crime. Thus, the article analyzes the history of the development of domestic legislation, as well as the modern legislation of a number of states (in terms of the protection of the rights and freedoms of minors). The scientific novelty of the study is to identify the main patterns and analyze the legislation providing for responsibility for crimes against minors throughout the entire period of the Russian state, as well as its comparison with the criminal legislation of a number of foreign states. As a result of this work, an analysis of the criminal law legislation of such countries as the Russian Federation, Kazakhstan, Ukraine, Belarus, Azerbaijan, Turkmenistan, Lithuania, Germany, China, Korea, Spain, France, and the USA was carried out.

Keywords: legislation, involvement of a minor in committing a crime, involvement of a minor in committing antisocial acts, responsibility, comparative analysis, Criminal Code of the Russian Federation.
$\mathbf{H}$ а протяжении всего периода развития цивилизованного общества проблема воспитания подрастающего поколения имела особую актуальность. Поколения, от которого во многом зависит будущее конкретной страны. Исходя из этого, данная проблема всегда находила свое отражение как на общественном, так и на государственном уровне, поскольку ребенок является одной из наиболее уязвимых в социально - правовом отношении групп населения, то защита его прав и свобод должна иметь для государства одно из наиболее приоритетных направлений. Так, одним из важнейших правовых средств, назначением которого является обеспечение защиты ребенка от общественно - опасных воздействий выступает - уголовный закон.

\author{
Авдеев Иван Сергеевич \\ Соискатель, Национальный исследовательский \\ Томский государственный университет \\ is_avdeev20041995@mail.ru
}

Аннотация. Целью данного исследования является проведение анализа развития отечественного и зарубежного законодательства, предусматривающего ответственность за вовлечение несовершеннолетнего в совершение преступления. Так, в статье анализируется история развития отечественного законодательства, а также современное законодательство ряда государств (в части защиты прав и свобод несовершеннолетних). Научная новизна исследования заключается в выявлении основных закономерностей и анализа законодательства, предусматривающего ответственность за преступления против несовершеннолетних на протяжении всего периода Российского государства, а также его сравнения с уголовным законодательством ряда иностранный государств. В результате данной работы был проведен анализ уголовно - правового законодательства таких стран как Российская Федерация, Казахстан, Украина, Беларусь, Азербайджан, Туркменистан, Литва, Германия, Китай, Корея, Испания, Франция, США.

Ключевые слова: законодательство, вовлечение несовершеннолетнего в совершение преступления, вовлечение несовершеннолетнего в совершение антиобщественных действий, ответственность, сравнительный анализ, уголовный кодекс Российской Федерации.

Любое преступление, направленное на нарушение прав и законных интересов несовершеннолетних, влечет за собой большие негативные последствия. В результате вовлечения несовершеннолетнего в совершение преступления происходит отрицательное воздействие на процессы духовно - нравственного, психического и физического развития несовершеннолетних, что чаще приводит к искаженному, деформированному представлению об определенных социальных, нравственных, мировоззренческих ценностях. Кроме того, искаженное представление, происходящее в нравственной сфере несовершеннолетних, приводит в дальнейшем к их противоправному поведению, то есть к росту преступности среди несовершеннолетних. 
Таким образом, в данной статье будет проведен сравнительный анализ законодательства (как отечественного, так и зарубежного), предусматривающего ответственность за вовлечение несовершеннолетнего в совершение преступления, а также вовлечения несовершеннолетнего в совершение антиобщественных действий.

Что касаемо истории развития отечественного законодательства, то в литературе можно встретить две точки зрения в части хронологических рамок.

Первая группа исследователей выделяет два периода развития отечественного законодательства:

1. с момента образования древнерусского государства (Х век н.э.) до Великой Октябрьской Социалистической революции (1917 г.);

2. с момента 1917 г. и до наших дней (в конкретном случае до 1 января 1997 года - до момента вступления в силу Уголовного кодекса Российской Федерации).

Вторая группа исследователей выделяет семь периодов развития отечественного законодательства:

1. X-XVI века (период действия «Русской правды», датированной от 1016 года н.э.);

2. XVII - XIX века (период действия «Соборного уложения», принятого 1649 года);

3. середина XIX - начало XX века (период действия «Уложения о наказаниях уголовных и исправительных», принятого 15 августа 1845 года);

4. 1903-1918 г.г. (период действия «Уголовного уложения», принятого 22 марта 1903 года);

5. 1918-1922 г.г. (период действия «Декретов и постановлений Совета народных комиссаров РСФСР» 1918-1920 г.г.);

6. 1922-1996 г.г. (период действия «Уголовного кодекса РСФСР» в редакции 1922, 1926 и 1960 года);

7. с 1996 г.- по настоящее время (действие Уголовного кодекса Российской Федерации», принятого 13 июня 1996 года).

Данная группа периодов будет подробно рассмотрена в данной статье, поскольку именно она наиболее подробно раскрывает особенности развития отечественного законодательства, предусматривающего ответственность за вовлечение несовершеннолетнего.

Первым документом, закрепившим права несовершеннолетних следует считать Русскую правду, которая является одним из древнейших кодифицированных нормативно - правовых актов. В данном документе отражены вопросы, касающиеся имущественных интересов детей в семейных и наследственных спорах, а также регламентирована ответствен- ность за злоупотребление родителями своей властью (принуждение к браку, пострижению в монашество). Прямых норм, регламентирующих ответственность за вовлечение несовершеннолетних, Русская правда не содержала.

Дальнейшее развитие норм ответственности за преступления против несовершеннолетних связано с изданием в 1649 году Соборного уложения. Нормы, закрепленные в данном документе способствовали защите личных и имущественных интересов несовершеннолетних. Кроме того, в документе особое внимание уделялось усилению ответственности за общеуголовные преступления, совершенные против детей. Также следует отметить, что Соборное уложение является первым нормативно - правовым актом, предусматривающим ответственность за вовлечение несовершеннолетнего в преступную деятельность, в том числе в занятие проституцией.

Одним из основополагающих документов, предусматривающих правовой статус несовершеннолетних следует считать «Уложение о наказаниях уголовных и исправительных», которое было принято 15 августа 1845 года. Так, раздел XI данного документа «О преступлениях против прав семейных» содержал четыре главы: «О преступлениях против союза брачного», «О злоупотреблении родительской властью и о преступлениях детей против родителей»; «О преступлениях против союза родственного»; «О злоупотреблении властью опекунов и родителей». Кроме того, данный документ впервые содержал в себе понятие «вовлечение» в контексте вовлечения несовершеннолетнего в преступную деятельность. Таким образом, исходя из анализа можно сделать вывод, что «Уложение о наказаниях уголовных и исправительных» являлась отправной точной в области права при регулировании правоотношения, связанных с вовлечением несовершеннолетнего в преступную деятельность. Однако, несмотря на все это, данный вопрос оставался довольно открытым и требовал в дальнейшем детальной разработки и нормативной регламентации.

Отправной точкой при развитии отечественного уголовного законодательства, предусматривающего ответственность за вовлечение несовершеннолетнего в преступную деятельность следует считать Уголовное уложение, принятое 22 марта 1903 года. Так, в отличии от предыдущих нормативно - правовых актов, вопросы, связанные с вовлечением несовершеннолетнего в совершение преступления нашли свое отражение в главе $\mathrm{XIX}$ «O преступлениях против прав семейственных», поскольку в ней появилась категория преступлений, совершенных родителями в отношении детей, и преступления, совершенные непосредствен- 
ного детьми. Также предусматривалась уголовная ответственность родителей за совершение их детьми различного рода преступлений (суд мог приговорить родителя как к тюремному заключению, так к лишению власти над несовершеннолетним (в н.в.- лишение родительских прав)). Кроме того, данный документ в той или иной степени отражал нормы предшествующих нормативно - правовых актов, предусматривающих ответственность за вовлечение несовершеннолетнего к «безнравственному занятию», за принуждение к вступлению в брак, за ненадлежащий надзор за несовершеннолетним, который в последующем совершил уголовно - наказуемое деяние.

Наиболее значимыми нормативно - правовыми актами также следует считать: декрет Совета Народных Комиссаров РСФСР от 14 января 1918 года «О комиссиях для несовершеннолетних», постановление Народного Комиссариата Юстиции РСФСР от 12 декабря 1919 года «Руководящие начала по уголовному праву РСФСР», декрет Совета Народных Комиссаров РСФСР от 4 марта 1920 года «О делах несовершеннолетних, обвиняемых в общественно - опасных действиях». Исходя из анализа данных документов можно сделать вывод, что они предусматривали ответственность за соучастие в преступлении взрослых совместно с несовершеннолетними. Кроме того, они предусматривали ответственность за непосредственное вовлечение несовершеннолетних в преступную деятельность. На мой взгляд, принятию данных норм способствовала напряженная экономическая ситуация в стране, «жертвами» которой зачастую становились дети, как одна из наиболее уязвимых категорий граждан.

Что касается Уголовного кодекса РСФСР, утвержденного 27.10.1960 года, то в ст. 210 предусматривалась ответственность за «Вовлечение несовершеннолетнего в преступную деятельность». Также следует отметить, что УК РСФСР не имел отдельной главы, предусматривающей ответственность за преступления против несовершеннолетних. Однако, при его создании советскими учеными высказывались мнения о создании отдельной главы (о преступлениях против семьи и молодежи), однако законодательного закрепления данная позиция не получила, и нормы были «разбросаны» по разным главам УК РСФСР.

В настоящее время, уголовная ответственность за вовлечение несовершеннолетнего предусмотрена Уголовным кодексом Российской Федерации, принятым 13 июня 1996 года, а именно ст. 150 «Вовлечение несовершеннолетнего в совершение преступления» и ст. 151 «Вовлечение несовершеннолетнего в совершение антиобщественных действий». Кроме того, особенности уголовной ответственности и наказания не- совершеннолетних предусмотрена гл. 14 «Особенности уголовной ответственности и наказания несовершеннолетних».

Что касается зарубежного законодательства, предусматривающего ответственность за вовлечение, то здесь стоит отметить, что в уголовном кодексе ряда государств, таких как Германия, КНР, Испания, Китай, Франция, США не содержится самостоятельная глава, предусматривающая ответственность против несовершеннолетних.

Так, ст. 295 Уголовного кодекса Китайской народной республики предусматривает: «Обучение способам преступной деятельности наказывается лишением свободы на срок до 5 лет, арестом или надзором; при отягчающих обстоятельствах наказывается лишением свободы на срок свыше 5 лет; при особо отягчающих обстоятельствах наказывается бессрочным лишением свободы». Ст. 347 Уголовного кодекса Китайской народной республики предусматривает ответственность за «Использование, Подстрекательство несовершеннолетних к пропаганде, продаже, транспортировке и изготовлению наркотиков или продажа наркотиков несовершеннолетним».

Уголовное законодательство США предусматривает ответственность за «Использование несовершеннолетних в качестве распространителей наркотических средств». При этом при повторном совершении данного деяния, уголовная ответственность значительно возрастает. Кроме того, в отдельных штатах США предусмотрена ответственность за «Привлечение несовершеннолетних или непосредственному его перемещению между штатами, сопровождающееся перевозкой материалов и веществ, распространение которых полностью или частично (путем лицензирования) запрещены на территории США.

Уголовный кодекс Германии определяет четкие возвратные границы категории понятия «несовершеннолетний». При этом предусматривает понятие «торговля людьми», один из пунктов которого является склонение несовершеннолетнего к занятию проституцией и другим действиям сексуального характера, который имеет квалифицированный состав - по способам склонения (угрозы, насилие, хитрость и т.д.).

Согласно Уголовного кодекса Испании предусмотрена ответственность за склонение несовершеннолетнего к бродяжничеству и попрошайничеству (ст.ст. 225, 233 УК Испании), использование несовершеннолетнего в эксгибиционистских или порнографических представлениях (ст. 189 УК Испании), принуждение и побуждение к занятию несовершеннолетнего проституци- 
ей (ст. 187 УК Испании), сексуальное злоупотребление с лицом от 12 до 16 лет (ст. 183 УК Испании).

Уголовный кодекс Франции предусматривает ответственность за подстрекательство несовершеннолетнего к употреблению наркотических средств, алкогольных напитков, попрошайничеству, систематическому совершению преступлений или проступков (ст.ст. 227/18-227/21 УК Франции); развращение несовершеннолетнего и его использование в действиях порнографического характера (ст.ст. 227/22-227/24 УК Франции); сексуальные посягательства на личность несовершеннолетнего со стороны совершеннолетнего лица.

Исходя из анализа уголовного законодательства стран СНГ можно сделать вывод о том, что в уголовных кодексах Казахстана, Украины, Беларуси, Азербайджана, Туркменистана, Литвы имеются составы преступлений, в той или иной степени отражающие понятие «вовлечение несовершеннолетнего в совершение преступлений». Это объясняется тем, что законодательство этих стран дублирует положения УК РСФСР.

Таким образом, на основании проведенного исследования можно сделать вывод о том, что проблема вовлечения несовершеннолетнего в совершение пре- ступления была актуальна практически на всем протяжении российской и мировой истории. Так, первые нормы, предусматривающие ответственность за данный вид преступления, нашли свое отражение в Русской правде, которая была издана в XI веке н.э. И до настоящего времени данные нормы продолжают активно развиваться. Тому подтверждением служит множество нормативно правовых актов, принятых в разные исторические периоды: Соборное уложение 1649 года, Уложение о уголовных и исправительных наказаниях 1845 года, Декреты СНК революционного периода времени, УК РСФСР. Во всех указанных правовых актах государство предусматривало суровые санкции за преступления, посягающие на нормальное развитие подростков.

Развитие норм об ответственности за вовлечение несовершеннолетнего в совершение преступления в зарубежном уголовном законодательстве не только началось раньше чем в России, но и развивалось несколько быстрее, чем отечественное законодательство. Из чего можно сделать вывод, что законодательные органы таких стран, как США, Испания, Франция, Корея, а также бывшие страны СССР, уделяют большое внимание ответственности за преступления против несовершеннолетних, предусматривая за их совершение самые суровые наказания.

\section{ЛИТЕРАТУРА}

1. Уголовный кодекс Российской Федерации от 13.06 .1996 г. (в ред. Ф3 № 436-Ф3 от 19 декабря 2016 г.) // СПС «Консультант Плюс».

2. Русская правда — сборник правовых норм Киевской Руси 1016 год.н.э. [Электронный ресурс] http://istorichka.edusite.ru/p19aa1.html (Дата 0бращения: 01 ноября 2021 г.).

3. Соборное уложение — свод законов Русского царства. 1649 год. н.э. [Электронный ресурс] http://www.hist.msu.ru/ER/Etext/1649.htmm (Дата 0бращения: 01 ноября 2021 г.).

4. Уложение о наказаниях уголовных и исправительных. 1845 год. [Электронный ресурс] http://музейреформ.рф/node/13654 (Дата обращения: 01 ноября 2021 г.).

5. Уголовное уложение 1903 года. [Электронный ресурc] http://library6.com/item/ 553030 (Дата обращения: 01 ноября 2021 г.).

6. Декрет Совета Народных Комиссаров РСФСР от 14 января 1918 г. «0 комиссиях по делам несовершеннолетних» // СПС «КонсультантПлюс».

7. Постановление Наркомюста РСФСР от 12 декабря 1919 г. «Руководящие начала по уголовному праву Р.С.Ф.С.Р.» // СПС «КонсультантПлюс».

8. Декрет Совета Народных Комиссаров РСФСР от 4 марта 1920 г. «0 делах о несовершеннолетних, обвиняемых в общественно-опасных действиях» // СПС «КонсультантПлюс».

9. Постановление ВЦИК от 1 июня 1922 г. «0 введении в действие Уголовного Кодекса Р.С.Ф.С.Р.» (вместе с «Уголовным Кодексом Р.С.Ф.С.Р.») // СПС «КонсультантПлюс».

10. Постановление ВЦИК от 22.11.1926 «0 введении в действие Уголовного Кодекса Р.С.Ф.С.Р. редакции 1926 года» (вместе с «Уголовным Кодексом Р.С.Ф.С.Р.») // СПС «КонсультантПлюс».

11. Уголовный кодекс РСФСР (утвержден Верховным Советом РСФСР 27 октября 1960 г.) // СПС «КонсультантПлюс».

12. Кодекс Соединенных Штатов Америки, Кодекс (ША [Электронный ресурс] http://constitutions.ru/?p=5849 (Дата обращения: 01 ноября 2021 г.).

13. Уголовный кодекс Германии [Электронный ресурс] http://constitutions.ru/?p=5854 (Дата обращения: 01 ноября 2021 г.).

14. Уголовный кодекс КНР. [Электронный ресурс] // http://asia-business.ru/law/law1/criminalcode/code/ (Дата обращения: 01 ноября 2021 года).

15. Уголовный Кодекс Королевства Испания [Электронный ресурс] http://newrespublika.ru/topic/19286-ugolovnyj-kodeks-korolevstva-ispaniia/ (Дата 0бращения: 01 ноября 2021 г.).

16. Уголовный кодекс Республики Беларусь [Электронный ресурс] // http://уголовный-кодекс.бел/statya-172 Дата обращения: ноября 2021 г.). 
17. Уголовный кодекс Республики Казахстан [Электронный ресурс] // http://online.zakon.kz/m/Document/?doc_id=31575252\#pos=94;-46\&sel_ link=1004096048 (Дата обращения: 01 ноября 2021 г.).

18. Уголовный кодекс Республики Украины. [Электронный ресурс] // http://kodeksy.com.ua/ka/ugolovnyj_kodeks_ukraini.htm (Дата обращения: 01 ноября 2021 г.).

19. Уголовный кодекс Франции 1992 года. [Электронный ресурс] http://constitutions.ru/?p=5859 (Дата обращения: 01 ноября 2021 г.).

(с Авдеев Иван Сергеевич ( is_avdeev20041995@mail.ru ).

Журнал «Современная наука: актуальные проблемы теории и практики»

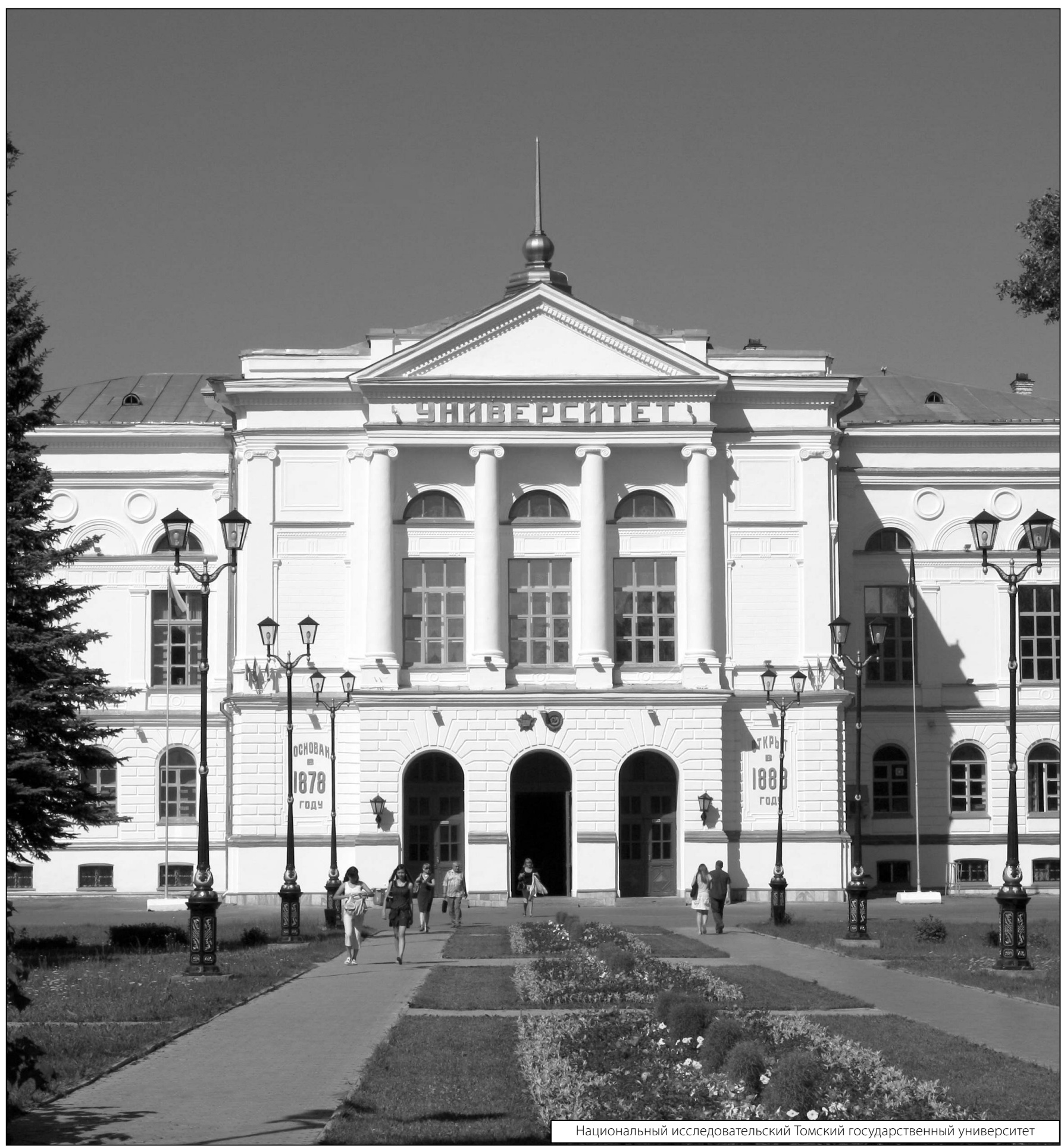

